\title{
Some Ethnophytomedical Aspects and Conservation Strategy of Several Medicinal Plants in Java, Indonesia
}

\author{
HARINI M. SANGAT, INGE LARASHATI \\ Herbarium Bogoriense, Indonesian Institute of Sciences, Bogor 16002
}

Received: 15 April 2002. Accepted: 29 April 2002

\begin{abstract}
The importance of medicinal plants for the preparation of "jamu" has been recognized in Indonesia and especially Java since ancient times. Jamu usually consists of blends of several kinds of plants or other natural materials. Jamu remains popular and there is an increasing demand for jamu in such diverse fields as health and beauty care, medical treatment and the preparation of fresh beverages. The problems result from the fact of most materials needed for preparation of jamu being natural resources. These materials are collected by the people in the forest and sold to the producers without thought for the conservation of these plants in nature with the consequence that some of the medicinal plants concerned have become difficult to find in the wild. Studies in the field in West, Central and East Java and at jamu enterprises and raw material sales centre show that several species of jamu raw material are very scarce. They should be classified as endangered. In this paper the significance of the endangered species as jamu in traditional Indonesian medicine is assessed and a strategy for conserving them "in situ and ex situ " is discussed.
\end{abstract}

(C) 2002 Jurusan Biologi FMIPA UNS Surakarta

Key words: conservation, medicinal plant, jamu, Java.

\section{INTRODUCTION}

The significance of medicinal plants in the traditional life of Indonesian people is high especially in the Javanese community. People use them to prepare for "jamu" ingredients to give traditional herbal medicine, usually consisting of blends of several kinds of plants or other natural materials.

Jamu is still in great demand in Indonesia. Many kinds of it are sold in shops and markets in elegant packages or as beverages ready to drink. Most Indonesian people believe that jamu increases health and resistance to disease. Jamu has long been used in the public health program to health care.

The increasing demand for jamu for health and beauty care, medicinal treatment or as fresh beverages makes its preparation and sale highly profitable, this in turn increasing demand for sources materials most of which are forest plants. In consequence these have become rare in nature. A strategy to conserve the several species of plants concerned in this paper.

\section{MATERIALS AND METHODS}

On the spot observation were made in several centers and enterprises, 'jamu gendong" seller interviewed and the literature reviewed. The jamu gendong sellers are familiar itinerants in West, Central and East Java. Usually they are women carrying jamu in bottles in baskets on their backs from door to door.

Employees in jamu factories or home industries were interviewed. The plant species used for preparation of jamu were identified with the assistance of the Herbarium Bogoriense and the Botanical Garden in Bogor, Indonesia and observed the ways in which they are used. 


\section{RESULTS AND DISCUSSIONS}

\section{Ethnophytomedical conservations}

Jamu is worn as traditional medicinal plants. The drinking of jamu is a traditional form of health care passing from one generation with little change. The word "jamu" is Javanese in origin. The origin and development of the tradition is uncertain.

Jamu contains not only ingredients directly curing specific illnesses but others enhancing resistance to illness in general. Uses include:

- Teenagers: medicinal herb for young girls, particularly used by girls before marriage. Married women: medicinal herb is consumed to enhance womanhood.

- Pregnant women: use "mbobot" medicinal herb and after childbirth use "selapan" medicinal herb.

- Men: medicinal herb is used to increase strength.

Both observations and interviews indicated that several species of medicinal plants conceived have become difficult to find (Table 1). In the old days the several depleted species were very important ingredients of tonic and aphrodisiacs and in health and beauty care. Nowadays they are rare and expensive so the producers change the ingredients to related species that are easier and cheaper to find- For example in the preparation of jamu sehat laki-laki", that is strongman's jamu, traditionally using "sintok" (Cinnamomum sintoc) as raw material, this ingredient has been replaced by "kayu manis" or cinnamon (Cinnamomum burmanni). Both species belong to the family Lauraceae.

Such changes of- raw material will reduce the taste, activity and power of jamu. Traditionally it was believed that the original ingredients of jamu were specific pairs of materials and that neither of the pairs could be changed, For example, "sintok-seprantu", "sintok" (Cinnamomum sintoc) pairs with "seprantu" (Sindora sumatrana) and "adaspulasari", "adas" (Foeniculum vulgare) pairs with "pulasari" (Alyxia reinwardtii).

\section{The endangered species and their conservation}

Modem trends in jamu production are towards greater consumption and greater convenience in use, resulting in increased demand for raw materials. They are still mainly collected in the wild and in particular from forests. Only a few producers have started cultivation of jamu garden. Most of them obtain raw materials from small farmers or collectors who collect the rhizome, bark, leaves and flowers or whole plants Iwithout thought for the conservation of these natural resources.

Steenis-Krusseman (1953), Heyne (1950) and Burkill (1935), listed no fewer than 1000 species of plants which have been used for generation by local inhabitants in preparing a variety of traditional medicines. Soepadmo (1979) has pointed out that many of these plants live in forests and can become rare before their medicinal properties can be examined scientifically. Whole habitats are threatened as a direct effect of increasing population, low standards and of living high demand for raw materials. Many of the primary forests are being clear felled and transformed into agricultural land. These activities threaten the survival of many species of plants including medicinal plants.

Field observation on the endangered species of medicinal plants directly threatened especially in Java, i.e. Alyxia reinwardtii. Cassia tora, Cinnamomum sintoc, Curcuma mangga, Cryptocarya massoy, Elaeocarpus sphaericus, Parameria laevigata, Pimpinella alpina, and Stelechocarpus burahol, showed that the plants still surviving were old and unproductive. Young plants (seedlings) nearby were very few in number and were mainly young plants growing only slowly.

In several places Alexia reinwardtii. Curcuma mangga, Parameria laevigata, Pimpinella alpina and Stelechocarpus burahol are cultivated by inhabitants in their gardens at home or close to villages. But only in limited number just enough for family use. The other species Cassia tora, Cinnamomum sintoc, Cryptocarya massoy and Elaeocarpus' sphaericus are only rarely cultivated. Some collectors follow good conservation practice. For example, on the Dieng plateau the people pick only the top shoots of Pimpinella alpina and leave lower parts of the plant, so the plant can recover naturally. Cultivation is the best way to secure the continuity of supply but there has been little study of the techniques required, given the urgency of the situation. So the primacy of jamu resources still depends on nature. I suggest that these species should be classified as endangered in Indonesia. Botanical gardens or arboreta are good places for ex-situ conservation. Their germ plasma 
Table 1. The species of jamu raw material that have become rare.

\begin{tabular}{|c|c|c|c|c|c|c|}
\hline No. & Species & Family & Local name & $\begin{array}{l}\text { Part of } \\
\text { plant }\end{array}$ & Kind of jamu & $\begin{array}{l}\text { Use and mode of } \\
\text { application }\end{array}$ \\
\hline 1. & Alyxia reinwardtii BI. & Apocynaceae & Pulasari & Bark & $\begin{array}{l}\text { Jamu "beras kencur \& cabe puyang". } \\
\text { Effective as tonicum, to increase resistance to } \\
\text { disease, reduce muscular fatigue (for man } \\
\text { and woman). }\end{array}$ & $\begin{array}{l}\text { Odor and flavor, stomachic, } \\
\text { anti-spasmodic and } \\
\text { carminative }\end{array}$ \\
\hline \multirow[t]{2}{*}{2.} & \multirow[t]{2}{*}{ Cassia tora L. } & \multirow[t]{2}{*}{ Fabaceae } & \multirow[t]{2}{*}{ Ketapang kecil } & \multirow{2}{*}{$\begin{array}{l}\text { Seed \& } \\
\text { leaves }\end{array}$} & To protect eye, & Tonic for the eyes \\
\hline & & & & & $\begin{array}{l}\text { Jamu "perut kembung", to remedy } \\
\text { constipation }\end{array}$ & Purgative/laxative \\
\hline 3. & Cinnamomum sintoc BI. & Lauraceae & Sintok & Bark & $\begin{array}{l}\text { Jamu "sehat wanita", to increase strength and } \\
\text { resistance to disease. }\end{array}$ & Tonic, spasmodic \\
\hline 4. & $\begin{array}{l}\text { Curcuma mangga Val. \& } \\
\text { Zijp. }\end{array}$ & Zingiberaceae & Temu mangga & Rhizome & Jamu "sehat wanita", & To treat abdominal illness \\
\hline 5. & $\begin{array}{l}\text { Cryptocarya massoy } \\
\text { (Oken) Kosterm. }\end{array}$ & Lauraceae & Mesoyi & Bark & $\begin{array}{l}\text { Jamu "sehat wanita", to stimulate recovery } \\
\text { after childbirth and restore vitality. }\end{array}$ & $\begin{array}{l}\text { For woman after childbirth, } \\
\text { to improve odor as tonic, } \\
\text { and spasmodic }\end{array}$ \\
\hline 6. & $\begin{array}{l}\text { Elaeocarpus sphaericus } \\
\text { (Gaert.) K. Schum. }\end{array}$ & Elaeocarpaceae & Jenitri & Fruit & $\begin{array}{l}\text { Jamu "pelancar seni", to protect urinary } \\
\text { system as tonic. }\end{array}$ & Diuretic \\
\hline 7. & $\begin{array}{l}\text { Parameria laevigata } \\
\text { (Juss.) Moldenke }\end{array}$ & Apocynaceae & Kayu rapet & Bark & $\begin{array}{l}\text { Jamu "sehat wanita", to restore and stimulate } \\
\text { endocrine system after childbirth. }\end{array}$ & After parturition \\
\hline 8. & Pimpinella alpina Koord. & Apiaceae & Purwoceng & Root & $\begin{array}{l}\text { Jamu "sehat laki-laki", to make a man strong } \\
\text { especially in relationship with sex activity. }\end{array}$ & Diuretic, aphrodisiac \\
\hline 9. & $\begin{array}{l}\text { Stelechocarpus burahol } \\
\text { Hook.f. \& Th. }\end{array}$ & Annonaceae & Burahol & Fruit & $\begin{array}{l}\text { Jamu "awet ayu", for use in the cosmetic } \\
\text { industry. }\end{array}$ & $\begin{array}{l}\text { To make sweat fragrant } \\
\text { and as diuretic }\end{array}$ \\
\hline
\end{tabular}


Table 2. Distribution of endangered medicinal plants.

\begin{tabular}{|c|c|c|c|c|c|c|c|c|c|}
\hline No. & Species & Sumatera & Kalimantan & Sulawesi & $\begin{array}{c}\text { Nusa } \\
\text { Tenggara }\end{array}$ & Maluku & Irian & Java & Observation in Java \\
\hline 1. & Alyxia reinwardtii Bl. & Banka $^{3}$ ) & - & - & - & - & - & $\left.\left.\mathrm{W}, \mathrm{C}, \mathrm{E}^{1}\right),{ }^{2}\right)$ & $\begin{array}{l}\text { Central Java: cultivated in } \\
\text { Wonogiri and Ambarawa. } \\
\text { Forest rare. }\end{array}$ \\
\hline 2. & Cassia tora L. & $\begin{array}{l}\text { Tropical rain } \\
\text { forest }^{2} \text { ) }\end{array}$ & Forest $^{2}$ ) & - & - & - & - & $\begin{array}{l}\text { W, C, E, Mad. } \\
\left.\left.\left.{ }^{1}\right),{ }^{2}\right),{ }^{3}\right)\end{array}$ & $\begin{array}{l}\text { W, C, E, Mad, teak forest } \\
\text { wild. }\end{array}$ \\
\hline 3. & Cinnamomum sintoc BI. & Forest $^{2}$ ) & Forest $^{2}$ ) & - & - & - & - & $\begin{array}{l}\text { W, C, E, Mad. } \\
\left.\left.\left.{ }^{1}\right),{ }^{2}\right),{ }^{3}\right)\end{array}$ & $\begin{array}{l}\text { West Java forest (700- } \\
1500 \text { m asl.), wild, rare. }\end{array}$ \\
\hline 4. & $\begin{array}{l}\text { Curcuma mangga Val. } \\
\text { \& Zijp. }\end{array}$ & - & - & - & - & - & - & $\begin{array}{l}\text { W, C, E, Mad. } \\
\text { 1) }\end{array}$ & $\begin{array}{l}\text { West Java, cultivated in } \\
\text { home garden, rare. }\end{array}$ \\
\hline 5. & $\begin{array}{l}\text { Cryptocarya massoy } \\
\text { (Oken) Kosterm. }\end{array}$ & Forest $^{2}$ ) & Forest ${ }^{3}$ ) & $\begin{array}{l}\text { Makassar } \\
3 \text { ) }\end{array}$ & Bali $^{3}$ ) & Ternate $^{3}$ ) & Fakfak $^{3}$ ) & $\begin{array}{l}\text { W, C, E, Mad. } \\
3 \text { ) }\end{array}$ & $\mathrm{W}, \mathrm{C}, \mathrm{E}$, forest wild, rare. \\
\hline 6. & $\begin{array}{l}\text { Elaeocarpus sphaericus } \\
\text { (Gaert.) K. Schum. }\end{array}$ & - & - & Forest $^{2}$ ) & - & - & - & $\begin{array}{l}\text { W, C, E, Mad. } \\
\left.\left.{ }^{1}\right),{ }^{3}\right)\end{array}$ & $\begin{array}{l}\text { Trenggalek, Wonosobo, } \\
\text { Tasikmalaya, Ciamis } \\
\text { forest ( } \pm 1400 \mathrm{~m} \text { asl.) }\end{array}$ \\
\hline 7. & $\begin{array}{l}\text { Parameria laevigata } \\
\text { (Juss.) Moldenke }\end{array}$ & - & Forest $^{3}$ ) & - & Bali $^{3}$ ) & - & - & $\begin{array}{l}\left.\left.W, C, E,{ }^{1}\right),{ }^{2}\right) \\
\left.{ }_{3}\right)\end{array}$ & $\begin{array}{l}\text { W, C, E, teak forest, wild, } \\
\text { rare, sometimes } \\
\text { cultivated. }\end{array}$ \\
\hline 8. & $\begin{array}{l}\text { Pimpinella alpina } \\
\text { Koord. }\end{array}$ & - & - & - & - & - & - & $\left.\left.\underset{(3)}{W}, C, E,{ }^{1}\right),{ }^{2}\right)$ & $\begin{array}{l}\text { W, C, E, rare, } \\
\text { mountainous area (1800- } \\
3300 \text { m. asl.) }\end{array}$ \\
\hline 9. & $\begin{array}{l}\text { Stelechocarpus burahol } \\
\text { Hook.f. \& Th. }\end{array}$ & - & - & - & - & - & - & $\left.\left.\mathrm{W}, \mathrm{C}, \mathrm{E},{ }^{1}\right),{ }^{3}\right)$ & $\begin{array}{l}\text { W, C, E, rare, humid } \\
\text { forest, cultivated as } \\
\text { ornamental tree. }\end{array}$ \\
\hline
\end{tabular}

Annotations: ${ }^{1}$ ) Backer and Bakhuizen v.d. Brink (1963), ${ }^{2}$ ) Burkill (1935), ${ }^{3}$ ) Heyne (1950); W: west, C: central, E: east, Mad.: Madura. 
must be preserved and their medicinal properties studied.

Seed storage, meristem or tissue culture storage or pollen storage are the other methods that can be used for ex-situ conservation. Such methods are more economical and practical since gardens need specialized knowledge (Hughes, 1978).

Conservation can be done in their habitat in nature (in-situ conservation). The habitat can be protected against disturbance by a government regulation. Nature reserves and forest reserves are examples of in-situ conservation.

\section{REFERENCES}

Backer, C.A. and R.C. Bakhuizen van den Brink. 1963. Flora of Java. Vol. I. Groningen: Wolters Noordhoff.
Backer, C.A. and R.C. Bakhuizen van den Brink. 1965. Flora of Java. Vol. II. Groningen: Wolters Noordhoff.

Backer, C.A. and R.C. Bakhuizen van den Brink. 1968. Flora of Java. Vol. III. Groningen: Wolters Noordhoff.

Burkill, I.H. 1935. A Dictionary of the Economic Products of the Malay Peninsula. Vol. I. London: Governments of the Straits Settlements and Federated Malay States by the Crown Agents for the Colonies.

Heyne, K. 1950. De nuttige planten van Indonesia. Bandung: Van Hoeve's Gravenhage,.

Hughes, J.G. 1978. Conservation of Plant Genetic Resources. Birmingham: University of Ashton.

Steenis-Krusseman, M.H. van. 1953. Selected Indonesian medicinal plants. Bull. Org. Sci. Res. Indonesia: 18.

Soepadrno, B. 1979. The role of tropical botanical gardens in the conservation of threatened valuable plant genetic resources in Southeast Asia. In: Survival or Extinction. Synge $\mathrm{H}$. and $\mathrm{H}$. Townsend (eds.). London: Royal Botanic Gardens Kew. 